GLOBAL JOURNAL OF PURE AND APPLIED SCIENCES VOL. 22, 2016: 101-114 COPYRIGHTC BACHUDO SCIENCE CO. LTD PRINTED IN NIGERIA ISSN 1118-0579 www.globaljournalseries.com, Email: info@globaljournalseries.com

\title{
ASSESSMENT OF TRACE METAL CONTAMINATION OF SOILS AROUND OLUYOLE INDUSTRIAL ESTATE, IBADAN, SOUTHWESTERN NIGERIA
}

ROLAND A. ISIBOR

(Received 11 March 2016; Revision Accepted 15 April 2016)

\begin{abstract}
This study was carried out to determine the level of metals contamination of the soils around Oluyole industrial estate in Ibadan. Oluyole industrial estate has heavy concentration of manufacturing industries that generate a lot of waste products capable of introducing metals into the environment. Consequently, twenty-one topsoil samples were collected and analyzed for Molybdenum (Mo), Copper (Cu), Lead (Pb), Zinc (Zn), Nickel (Ni), Cobalt (Co), Manganese $(\mathrm{Mn})$, Scandium (Sc), Arsenic (As), Strontium (Sr), Cadmium (Cd), Vanadium (V) and Chromium (Cr) using the Inductively Coupled Plasma Mass Spectrometry (ICP-MS) technique. The degree of contamination was assessed using geoaccumulation index, contamination factor and degree of contamination. The mean concentration of metals was in the order: $\mathrm{Mn}>\mathrm{Cr}>\mathrm{Zn}>\mathrm{V}>\mathrm{Pb}>\mathrm{Cu}>\mathrm{Ni}>\mathrm{Sr}>\mathrm{Co}>\mathrm{Sc}>\mathrm{As}>\mathrm{Mo}>\mathrm{Cd}$. Factor analysis indicated three factor groupings. Factor 1 included $\mathrm{Mo}, \mathrm{Cu}, \mathrm{Pb}, \mathrm{Zn}, \mathrm{As}, \mathrm{Sr}$ and $\mathrm{Cd}$. Factor 2 is made up of $\mathrm{Ni}, \mathrm{Co}, \mathrm{Mn}, \mathrm{Sc}, \mathrm{Sr}, \mathrm{V}$ and $\mathrm{Cr}$ while Factor three included $\mathrm{Sc}$ and $\mathrm{V}$. These elemental associations were influenced mainly by lithology, geochemical affinity and anthropogenic activities. The geoaccumulation index showed that the soils were Practically uncontaminated to Moderately contaminated by $\mathrm{Zn}, \mathrm{Mn}$, Sc, and $\mathrm{Cr}$, Moderately contaminated by $\mathrm{Mo}, \mathrm{Cu}, \mathrm{Pb}, \mathrm{Ni}, \mathrm{Co}, \mathrm{As}, \mathrm{Cd}$ and Moderately to heavily contaminated by $\mathrm{Ni}$ and $\mathrm{Sr}$. Results of Contamination factor also showed that the soils have moderate contamination factor for all metals studied excepting Ni which has considerable contamination factor. The considerable degree of contamination with a value of 28.23 showed that the soils were highly polluted by the metals studied posing a potential health risk to human life and the environments.
\end{abstract}

KEYWORDS: Oluyole Industrial Estate, Contamination Factor, Degree of Contamination, Geo-accumulation index, Soils.

\section{INTRODUCTION}

In recent years, advancement in technology, urbanization and industrialization has contributed to the increase in the discharge of metals into the environment through media such as industrial effluents, auto-vehicle emissions, solid waste disposals, fertilizer application in soils and domestic wastes (Olukanmi and Adeoye, 2012). It has been shown that soils can act as depository for pollutant metals as a result of adsorption processes which bind these metals to it (Popoola et al, 2012). High concentration of these metals will eventually lead to the contamination of such soils. Soil contamination by trace metals is of major concern to man because at high concentration metals can cause harm to human life and the environment (Mtunzi et. al., 2015).

Ibadan city is underlain by the Precambrian Basement Complex of South-western Nigeria, which is part of the Proterozoic mobile belts located between the West-Africa and Congo Cratons. The Nigerian Basement Complex comprises of Migmatite-Gneiss Quartzite Complex; the metavolcanic and metasedimentary rocks (Schist Belts); the Pan-African Granitoids; and the Undeformed acid and basic dykes (Jones and Hockey, 1964; Rahaman, 1976; Dada, 2006). The basement complex has been affected by four major orogenies including the Liberian $(2800 \pm 200 \mathrm{my})$,

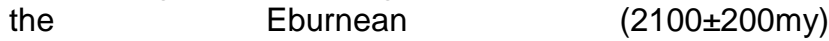

Kibarian (1100 $\pm 250 \mathrm{my})$, and the Pan African (600 \pm 150 my) (Rahaman, 1988; Obaje, 2009; Olayinka, 1992).Soils are products of weathering of underlying rocks. Consequently, elemental concentrations in soils are influenced by lithogenic inputs as well as anthropogenic inputs. The elemental concentration in the soils of the Oluyole industrial estate will therefore be influenced by the underlying basement rocks as well as anthropogenic inputs particularly industrial emissions, and wastes.

The Oluyole industrial estate in lbadan is an area with heavy concentration of industries manufacturing different products. Prominent among these industries are Procter \& Gamble, Zartech, Yale, Steel Works, Obasanjo Farms, and 7Up Bottling Company. These industries generate a lot of wastes which contain trace metals that are introduced into the immediate environment as effluents and emissions. Metals that may be present in these effluents and emissions include lead, zinc, cadmium and nickel which are priority environmental pollutants. Assessing the pollutant status of Oluyole industrial estate is therefore relevant and of great importance.

This study, therefore, is aimed at determining the concentrations and degree of trace metals contamination of soils in the Oluyole industrial area of Ibadan using the level of soil metal concentration, Geoaccumulation index, Contamination factor and Degree of contamination.

Roland A. Isibor, Department of Earth Sciences, Ajayi Crowther University, Oyo, Oyo State, Nigeria 


\subsection{MATERIALS AND METHODS}

2.1. Study Area and Sampling

The study area is covered by the Ibadan 261

N.E sheet (scale 1:50,000) and lies within longitudes $3^{0} 50^{\prime} 30 \mathrm{E}$ and $3056^{\prime} 00 \mathrm{E}$ and latitude $7^{\circ} 17^{\prime} 30 \mathrm{~N}$ and $702300 \mathrm{~N}$ (Figure 1). The major area covered by this study is the Oluyole industrial estate. Three major landform units - hills, plains and river valley dominate the scenery of the study area. The hills are the most striking features of Ibadan town, although they constitute less than 5 percent of the total area, while the plains form extensive landform system in the area. The elevation is between $80 \mathrm{~m}$ and $210 \mathrm{~m}$ above sea level.
The third landform system is the river valley which are the narrowest landform in the area. Ibadan generally is characterized by two distinct climatic seasons; the rainy and dry seasons. Between March and October, Ibadan is under the influence of the moist maritime south-west monsoon winds which blow inland from the Atlantic Ocean. This period is marked by constant rainfall and is referred to as the rainy season. The dry season occurs from November to February when the dry dust laden winds blow from the Sahara desert. Within the two seasons there are slight variation in intensity of the rain and the dryness (Filani, 1982).

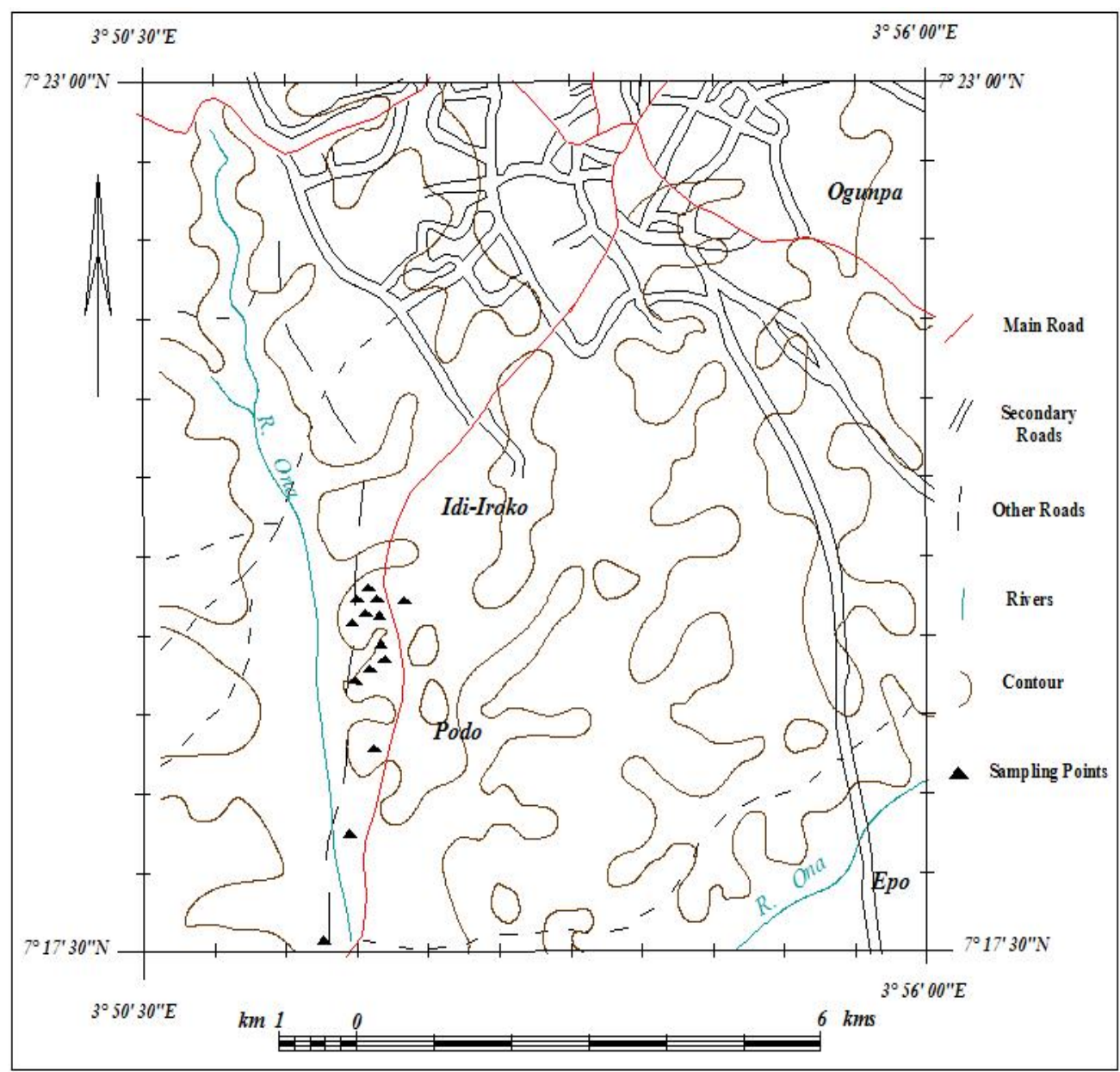

Fig. 1: Map of Oluyole industrialarea (extracted from Ibadan 261 N.E sheet: Scale 1:50,000)

Ibadan lies within the Precambrian Basement Complex of South-western Nigeria, which lies to the east of the West-African craton characterized by rocks formed by late Precambrian to early Paleozoic orogenies. The Nigerian basement complex extends westwards and is continuous with the Dahomeyan of the Dahomey-TogoGhana region. Rock types in the study area include quartzite, banded gneiss, augen gneiss, and amphibolites 


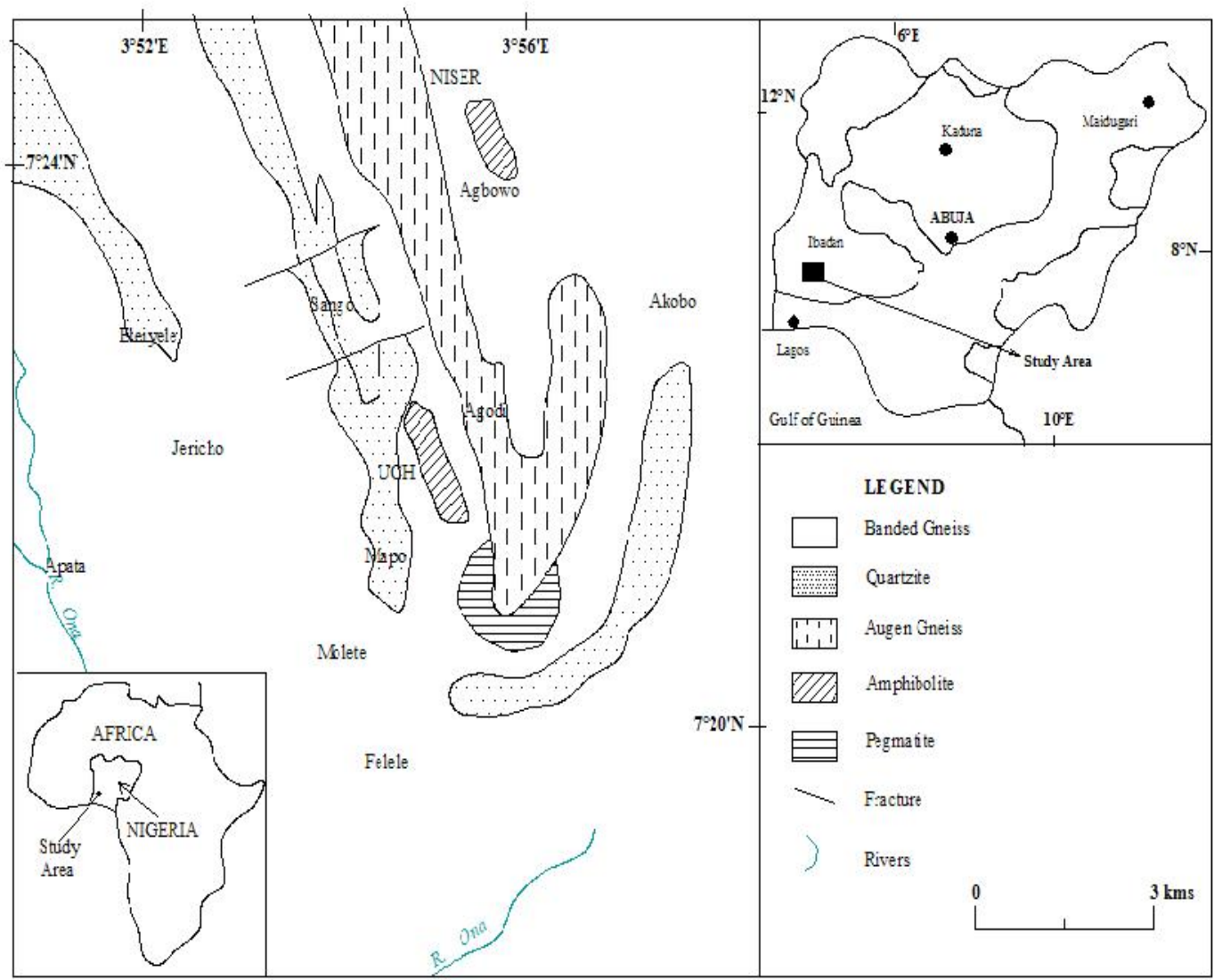

Fig. 2: Geological Map of Ibadan(modified after Grant, 1970).

Samples for this study were collected from the Oluyole industrial layout area of Ibadan (Fig. 3). Topsoil samples were collected randomly from 21 different locations around the industrial estate based on distribution of industries. They were collected at a depth of 0 to15 cm using plastic hand trowels and placed into polyethylene bags. The bags were marked to indicate the location of sample collection. The GPS readings for each sample point noted. 


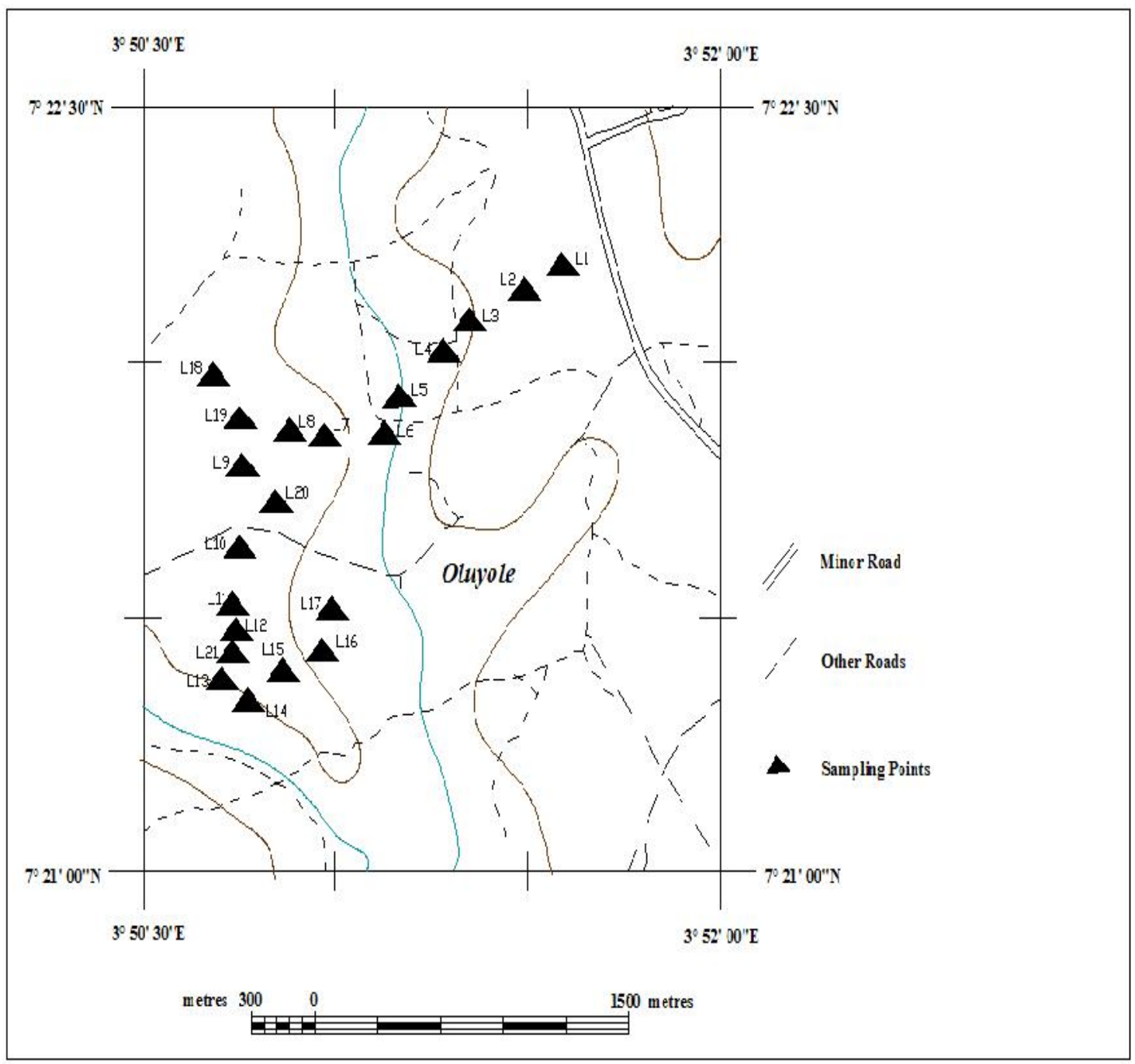

Fig. 3: Points of sample collection in Oluyole industrial estate.

The soil samples were air dried in the laboratory, and sieved through a $<0.075 \mathrm{~mm}$ polyethylene sieve to obtain fine grained samples for chemical analysis. Samples that were too clustered were disaggregated in a porcelain mortar with a pestle before sieving. The shaking was done by a mechanical sieve shaker and then the sieved portion $(<0.075 \mathrm{~mm})$ was collected and a fraction packed into air-tight polythene bag which was later sent to ACME laboratories, Vancouver, Canada for geochemical analysis.

Aqua Regia Digestion Method was employed to digest the soil samples. $0.5 \mathrm{~g}$ of each sample was digested using aqua regia $\left(0.5 \mathrm{ml} \mathrm{H}_{2} \mathrm{O}, 0.6 \mathrm{ml}\right.$ concentrated $\mathrm{HNO}_{3}$ and $1.8 \mathrm{ml}$ concentrated $\mathrm{HCl}$ ) for 2 hours at $95^{\circ} \mathrm{C}$. The solutions were then cooled and diluted to $10 \mathrm{ml}$ with deionized water in readiness for trace element determination of the samples.

\subsection{Sample Analysis}

The samples were analyzed using the Inductively Coupled Plasma Mass Spectrometry (ICPMS) technique. This was achieved by ionizing the sample with inductively coupled plasma and then using spectrometer to separate and quantify the ions. In inductively coupled plasma, plasma is energized by inductively heating the gas with an electrical coil. The plasmas used in spectro-chemical analysis are essentially electrically neutral, with each positive charge on an ion balanced by a free electron. The concentrations of elements in each sample was determined through calibration with certified reference material such as single or multi element reference standards.To ensure high - level dependability of geochemical analysis and reliability of the instrument, Quality Control and Quality Assurance (QC and QA) measures were taken. Analysis of sets of geochemical standards whose concentrations had previously been determined ensured the quality of the analysis. For this work, the United States Geological Survey (USGS) geochemical Standards GXR - 6, GXR - 5, GXR - 4, GXR - 2, and GXR - 1 were used to ascertain the degree of accuracy of the analytical instrument. Furthermore, to ensure the reliability of results of the analysis, blank samples were also analyzed at regular intervals during sample analyses.

\subsection{STATISTICAL ANALYSIS OF THE SOIL SAMPLES 2.4. Descriptive Statistics}

The mean, range and standard deviation were calculated for the samples. 


\subsection{Correlation Factor}

The degree of correlation between two variables is usually calculated by applying a coefficient of correlation on data containing the two variables. A perfect positive correlation between the two variables results in a coefficient of +1 , a perfect negative correlation between two variables results in a coefficient of -1 , and a total absence of correlation in a coefficient of 0 . Intermediate values between $+1,0$ and -1 are interpreted by degree of correlation. Thus, 0.96 indicates high positive correlation, -0.83 indicates high negative correlation and 0.09 indicates low positive correlation.

\subsection{CONTAMINATION INDICES}

\subsection{Geoaccumulation Index}

The Index of geoaccumulation (Igeo) was used for the assessment of soil contamination. It is computed using an equation developed by Muller (1969) and it is expressed mathematically as:

$$
\operatorname{lgeo}=\log _{2} \mathrm{Cn} / 1.5 \mathrm{Bn}
$$

Where:

$\mathrm{Cn}$ is the measured concentration of the element in the soil sample fraction

$\mathrm{Bn}$ is the geochemical background value (value from a controlled sample from Olapiti village an area free from industrial influence was used as background for this study).

The constant 1.5 allows for analysis of natural fluctuations in the content of a given substance in the environment and very small anthropogenic influences.

The soil quality can be subsequently referred to using the following values of Igeo as shown in Table 1.

Table 1: Classes of Geoaccumulation Index (Igeo) after Muller(1969).

\begin{tabular}{lll}
\hline Class & Igeo Value & Soil Quality \\
\hline 0 & Igeo $\leq 0$ & Practically Uncontaminated \\
1 & $0<\operatorname{lgeo} \leq 1$ & Uncontaminated to Moderately Contaminated \\
2 & $1<\operatorname{lgeo} \leq 2$ & Moderately Contaminated \\
3 & $2<\operatorname{lgeo} \leq 3$ & Moderately to Heavily Contaminated \\
4 & $3<\lg 00 \leq 4$ & Heavily Contaminated \\
5 & $4<\operatorname{lgeo} \leq 5$ & Heavy to Extremely Contaminated \\
6 & Igeo $>5$ & Extremely Contaminated \\
\hline
\end{tabular}

\subsection{Contamination Factor $\left(\mathrm{C}_{f}\right)$ and Degree of Contamination $\left(\mathbf{C}_{\mathrm{deg}}\right)$}

Soil contamination could also be assessed using the parameters: Contamination Factor and Degree of Contamination (Loska et al., 2004). In the version suggested by Hakanson (1980), soil contamination was assessed by comparing the observed concentration with pre-industrialized levels (average shale concentration).

$C_{f}^{i}=C_{0-i}^{i} / C_{n}^{i}$
Where:

$\mathbf{C}_{0-i}^{i}=$ mean concentration of metals from at least 5 sampling sites.

$\mathbf{C}_{\mathrm{n}}^{i}=$ pre - industrial concentration (for this work,soil sample from Olapiti village was used as background) of the individual metal

Contamination factor is a single element index (Table 2). The sum of the Contamination Factor for all studied metals yield the contamination degree $\mathrm{C}(\mathrm{deg})$ of the entire studied area and is represented by four classes (Table

3).

Table 2: Categories of Contamination factor

Class of Contamination factor

$\mathrm{C}_{\mathrm{f}<1}^{\prime}$

$1 \leq \mathrm{C}_{f}^{i}<3$

$3 \leq \mathrm{C}_{\mathrm{f}}<6$

$\leq \mathrm{C}_{\mathrm{f}}^{\mathrm{i}}$

\section{Soil Category}

\author{
low contamination factor \\ moderate contamination factor \\ Considerable contamination factor \\ Very high contamination factor
}


Table 3: Categories of Contamination degree

\begin{tabular}{ll}
\hline Class of Contamination degree & Soil Category \\
\hline $\mathrm{C}_{\operatorname{deg}} 8$ & low degree of contamination \\
$8 \leq \mathrm{C}_{\operatorname{deg}} 16$ & moderate degree of contamination \\
$16 \leq \mathrm{C}_{\operatorname{deg}} 32$ & Considerable degree of contamination \\
$32 \leq \mathrm{C}_{\operatorname{deg}}$ & Very high degree of contamination \\
\hline
\end{tabular}

3.0. RESULTS AND DISCUSSIONS

3.1. Elemental Concentrations and InterElemental Relationships

The analytical results for the soils of Oluyole industrial estate is presented in Table 4, while a summary of the descriptive statistics for the concentration of metals obtained is shown in the Appendix. Results shows that the mean value increased as follows:

$\mathrm{Mn}>\mathrm{Cr}>\mathrm{Zn}>\mathrm{V}>\mathrm{Pb}>\mathrm{Cu}>\mathrm{Ni}>\mathrm{Sr}>\mathrm{Co}>\mathrm{Sc}>\mathrm{As}>\mathrm{Mo}>\mathrm{Cd}$.

Table 4: Analytical results for the soils of Oluyole industrial area

\begin{tabular}{|c|c|c|c|c|c|c|c|c|c|c|c|c|c|}
\hline & $\begin{array}{l}\text { Mo } \\
\text { (ppm) }\end{array}$ & $\begin{array}{l}\mathrm{Cu} \\
\text { (ppm) }\end{array}$ & $\begin{array}{l}\mathrm{Pb} \\
\text { (ppm) }\end{array}$ & $\begin{array}{l}\mathrm{Zn} \\
\text { (ppm) }\end{array}$ & $\begin{array}{l}\mathrm{Ni} \\
\text { (ppm) }\end{array}$ & $\begin{array}{l}\text { Co } \\
\text { (ppm) }\end{array}$ & $\begin{array}{l}\text { Mn } \\
\text { (ppm) }\end{array}$ & $\begin{array}{l}\text { Sc } \\
\text { (ppm) }\end{array}$ & $\begin{array}{l}\text { As } \\
\text { (ppm) }\end{array}$ & $\begin{array}{l}\mathrm{Sr} \\
\text { (ppm) }\end{array}$ & $\begin{array}{l}\text { Cd } \\
\text { (ppm) }\end{array}$ & $\begin{array}{l}\mathrm{V} \\
\text { (ppm) }\end{array}$ & $\begin{array}{l}\text { Cr } \\
\text { (ppm) }\end{array}$ \\
\hline L1 & 2.5 & 60.3 & 69.0 & 178 & 23.2 & 18.1 & 629 & 1.6 & 1.5 & 22 & 0.4 & 63 & 81 \\
\hline L2 & 1.4 & 26.6 & 36.0 & 90 & 12.6 & 11.6 & 429 & 1.4 & 1.1 & 31 & 0.1 & 53 & 87 \\
\hline L3 & 1.3 & 60.1 & 113.9 & 147 & 18.1 & 30.2 & 1283 & 7.1 & 1.0 & 56 & 0.2 & 94 & 73 \\
\hline L4 & 2.2 & 76.0 & 270.8 & 243 & 18.2 & 20.1 & 975 & 2.6 & 3.4 & 90 & 0.3 & 70 & 77 \\
\hline L5 & 0.7 & 24.6 & 43.0 & 81 & 19.2 & 27.2 & 800 & 1.9 & 0.9 & 27 & 0.1 & 56 & 45 \\
\hline L6 & 1.0 & 39.1 & 50.0 & 106 & 17.4 & 13.9 & 596 & 3.2 & 0.8 & 21 & 0.1 & 49 & 52 \\
\hline L7 & 1.1 & 41.6 & 67.1 & 146 & 24.0 & 32.6 & 1062 & 4.0 & 1.2 & 18 & 0.2 & 80 & 96 \\
\hline L8 & 1.0 & 33.2 & 37.6 & 107 & 20.5 & 20.7 & 740 & 2.5 & 0.9 & 20 & 0.1 & 56 & 79 \\
\hline L9 & 1.2 & 37.2 & 26.7 & 49 & 75.8 & 42.5 & 975 & 2.8 & 1.7 & 52 & $<0.1$ & 113 & 145 \\
\hline L10 & 0.9 & 24.9 & 18.9 & 34 & 58.1 & 38.1 & 858 & 2.3 & 1.2 & 33 & $<0.1$ & 79 & 121 \\
\hline L11 & 0.6 & 17.5 & 14.1 & 26 & 29.0 & 17.1 & 416 & 7.5 & 1.0 & 20 & $<0.1$ & 57 & 93 \\
\hline L12 & 0.6 & 16.2 & 11.4 & 19 & 33.9 & 22.1 & 455 & 1.9 & 1.2 & 20 & $<0.1$ & 63 & 104 \\
\hline L13 & 0.8 & 40.3 & 26.4 & 76 & 94.3 & 60.3 & 1397 & 3.0 & 1.3 & 59 & $<0.1$ & 106 & 137 \\
\hline L14 & 1.0 & 24.9 & 18.8 & 27 & 47.7 & 34.3 & 749 & 5.9 & 1.9 & 20 & $<0.1$ & 97 & 143 \\
\hline L15 & 0.8 & 26.0 & 24.2 & 43 & 45.4 & 29.1 & 719 & 2.1 & 1.6 & 36 & $<0.1$ & 80 & 104 \\
\hline L16 & 1.0 & 27.8 & 34.5 & 67 & 26.7 & 19.2 & 469 & 3.6 & 1.1 & 21 & 0.2 & 60 & 93 \\
\hline L17 & 1.1 & 29.9 & 30.6 & 123 & 18.7 & 8.4 & 266 & 4.2 & 0.6 & 18 & 0.2 & 30 & 52 \\
\hline L18 & 1.2 & 27.3 & 26.9 & 89 & 50.3 & 33.0 & 749 & 2.3 & 1.4 & 35 & 0.2 & 73 & 101 \\
\hline L19 & 1.3 & 35.9 & 57.8 & 122 & 13.2 & 10.1 & 479 & 2.4 & 1.1 & 18 & 0.3 & 49 & 61 \\
\hline L20 & 2.2 & 39.9 & 92.2 & 110 & 20.5 & 23.8 & 843 & 4.8 & 2.1 & 13 & 0.1 & 127 & 78 \\
\hline L21 & 0.8 & 27.0 & 19.8 & 35 & 59.4 & 30.8 & 805 & 4.4 & 1.3 & 52 & $<0.1$ & 75 & 105 \\
\hline
\end{tabular}

The minimum value for Mo is $0.60 \mathrm{ppm}$ while the maximum value is $2.50 \mathrm{ppm}$. It has a mean value of $1.18 \mathrm{ppm}$ and standard deviation value of $0.52 \mathrm{ppm}$. $\mathrm{Cu}$ ranged from $16.20 \mathrm{ppm}$ to $76.00 \mathrm{ppm}$ and a mean value and standard deviation value of $35.06 \mathrm{ppm}$ and $14.83 \mathrm{ppm}$ respectively. $\mathrm{Pb}$ ranged from $11.40 \mathrm{ppm}$ to $270.80 \mathrm{ppm}$, with a mean value of 51.89 and standard deviation of 56.66. Zn has a mean value and standard deviation value of $91.33 \mathrm{ppm}$ and $56.80 \mathrm{ppm}$; it also ranged from $19.00 \mathrm{ppm}$ to $243.00 \mathrm{ppm}$.

The minimum value for $\mathrm{Ni}$ is $12.60 \mathrm{ppm}$, while the maximum value is $94.30 \mathrm{ppm}$. It has a mean value of $34.58 \mathrm{ppm}$ and standard deviation value of 22.32ppm. Co ranged from $8.40 \mathrm{ppm}$ to $60.30 \mathrm{ppm}$ with a mean value and standard deviation value of $25.87 \mathrm{ppm}$ and $12.23 \mathrm{ppm}$ respectively. $\mathrm{Mn}$ has a mean value of $747.33 \mathrm{ppm}$ and a standard deviation value of $287.64 \mathrm{ppm}$, and it also ranges from $266.00 \mathrm{ppm}$ to 1397.00ppm.

Sc ranged from $1.40 \mathrm{ppm}$ to $7.50 \mathrm{ppm}$, with a mean value of $3.40 \mathrm{ppm}$ and a standard deviation of
1.74. As has a minimum value of $0.60 \mathrm{ppm}$, maximum value of 4.30 a mean value of $1.35 \mathrm{ppm}$ and a standard deviation of 0.59 . Sr ranged from $13.00 \mathrm{ppm}$ to $90.00 \mathrm{ppm}$, with a mean value of $32.48 \mathrm{ppm}$ and a standard deviation of 19.21 . The minimum value for $\mathrm{Cd}$ is $0.09 \mathrm{ppm}$, while the maximum value is $0.40 \mathrm{ppm}$. It has a mean value of $0.15 \mathrm{ppm}$ and standard deviation value of $0.09 \mathrm{ppm}$. V ranged from $30.00 \mathrm{ppm}$ to $127.00 \mathrm{ppm}$, with a mean value of $72.86 \mathrm{ppm}$ and standard deviation value of $23.85 \mathrm{ppm}$. $\mathrm{Cr}$ ranged from $45.00 \mathrm{ppm}$ to $145.00 \mathrm{ppm}$ with a mean value and standard deviation value of $91.76 \mathrm{ppm}$ and $28.55 \mathrm{ppm}$ respectively.

The inter-elemental relationship as determined from the correlation matrix (Table 5 ) indicate a very strong relationship between $\mathrm{Pb}-\mathrm{Cu}, \mathrm{Zn}-\mathrm{Cu}, \mathrm{Zn}-\mathrm{Pb}, \mathrm{Co}-$ $\mathrm{Ni}$, Cr-Ni. A strong relationship is exhibited by $\mathrm{Cu}-\mathrm{Mo}$, $\mathrm{Zn}-\mathrm{Mo}, \mathrm{Mn}-\mathrm{Co}, \mathrm{As}-\mathrm{Pb}, \mathrm{Cd}-\mathrm{Zn}, \mathrm{V}-\mathrm{Co}, \mathrm{V}-\mathrm{Mn}, \mathrm{V}-\mathrm{Sc}, \mathrm{Cr}-\mathrm{Co}$. A fairly strong relationship is also established between $\mathrm{Pb}-\mathrm{Mo}$, Sc-Ni, Sc-Co, Sc-Mn, As-Mo, As-Cu, Sr-Cu, Sr$\mathrm{Pb}$, Sr-As, Cd-Mo, Cd-Cu, Cd-Pb, V-Ni, Cr-Co. 
Table 5: Correlation Matrix for metals in the soils of Oluyole industrial estate

\begin{tabular}{|l|l|l|l|l|l|l|l|l|l|l|l|l|l|}
\hline & $\mathrm{Mo}$ & $\mathrm{Cu}$ & $\mathrm{Pb}$ & $\mathrm{Zn}$ & $\mathrm{Ni}$ & $\mathrm{Co}$ & $\mathrm{Mn}$ & $\mathrm{Sc}$ & $\mathrm{As}$ & $\mathrm{Sr}$ & $\mathrm{Cd}$ & $\mathrm{V}$ & $\mathrm{Cr}$ \\
\hline $\mathrm{Mo}$ & 1.000 & & & & & & & & & & & & \\
$\mathrm{Cu}$ & .757 & 1.000 & & & & & & & & & & & \\
$\mathrm{~Pb}$ & .666 & .854 & 1.000 & & & & & & & & & & \\
$\mathrm{Zn}$ & .754 & .885 & .833 & 1.000 & & & & & & & & & \\
$\mathrm{Ni}$ & -.340 & -.206 & -.375 & -.508 & 1.000 & & & & & & & & \\
$\mathrm{Co}$ & -.247 & .003 & -.168 & -.301 & .873 & 1.000 & & & & & & & \\
$\mathrm{Mn}$ & .093 & .492 & .323 & .211 & .487 & .803 & 1.000 & & & & & & \\
$\mathrm{Sc}$ & .197 & .238 & .080 & -.041 & .587 & .674 & .661 & 1.000 & & & & & \\
$\mathrm{As}$ & .584 & .543 & .719 & .383 & .107 & .172 & .324 & .294 & 1.000 & & & & \\
$\mathrm{Sr}$ & .176 & .567 & .596 & .322 & .375 & .423 & .607 & .403 & .581 & 1.000 & & & \\
$\mathrm{Cd}$ & .678 & .666 & .531 & .767 & -.403 & -.360 & -.074 & -.199 & .243 & .107 & 1.000 & & \\
$\mathrm{~V}$ & .196 & .195 & .090 & -.138 & .557 & .730 & .718 & .811 & .469 & .300 & -.278 & 1.000 & \\
$\mathrm{Cr}$ & -.223 & -.216 & -.321 & -.525 & .834 & .746 & .374 & .435 & .270 & .245 & -.369 & .627 & 1.000 \\
\hline
\end{tabular}

\subsection{Factor Analysis}

A varimax-rotation analysis was applied to the data set to distinguish between the various components of the soil in order to evaluate the possible sources of metals in this study. The metals were divided into three distinct factor groupings with Eigen values higher than one.
Elemental loadings in these factors were given in Table 6 , and the factor loadings which are greater than 0.50 are significant in the interpretation of the data. Table 7 explains the total system variance of the metals in the soils.

Table 6: Factor Analysis showing the Rotated Component Matrix of the metals in the soils of Oluyole industrial estate

\begin{tabular}{|l|l|l|l|}
\hline & \multicolumn{3}{l}{ Component } \\
\hline & 1 & 2 & 3 \\
\hline $\mathrm{Mo}$ & .758 & -.268 & .494 \\
$\mathrm{Cu}$ & .939 & .146 & .151 \\
$\mathrm{~Pb}$ & .940 & .050 & .078 \\
$\mathrm{Zn}$ & .941 & -.173 & -.013 \\
$\mathrm{Ni}$ & -.384 & .835 & .175 \\
$\mathrm{Co}$ & -.204 & .889 & .285 \\
$\mathrm{Mn}$ & .294 & .775 & .293 \\
$\mathrm{Sc}$ & .035 & .583 & .678 \\
$\mathrm{As}$ & .591 & .279 & .417 \\
$\mathrm{Sr}$ & .553 & .742 & -.109 \\
$\mathrm{Cd}$ & .895 & -.145 & -.299 \\
$\mathrm{~V}$ & -.022 & .545 & .799 \\
$\mathrm{Cr}$ & -.381 & .661 & .327 \\
\hline
\end{tabular}

Extraction Method: Principal Component Analysis.

Factor 1: $\mathrm{Mo}, \mathrm{Cu}, \mathrm{Pb}, \mathrm{Zn}$, As and $\mathrm{Cd}$ (Felsic mineral-rich lithology, and anthropogenic influence)

Factor 2: Ni, Co, Mn, Sc, Sr, $\mathrm{V}$ and $\mathrm{Cr}$ (Geochemical affinity and mafic mineral-rich lithology)

Factor 3: Sc and V (Geochemical affinity and mafic mineral-rich lithology) 
Table 7: Total variance of metals in soils of Oluyole industrial estate

\begin{tabular}{|c|c|c|c|c|c|c|c|c|c|}
\hline \multirow[t]{2}{*}{ Component } & \multicolumn{3}{|c|}{ Initial Eigenvalues } & \multicolumn{3}{|c|}{$\begin{array}{l}\text { Extraction Sums of Squared } \\
\text { Loadings }\end{array}$} & \multicolumn{3}{|c|}{$\begin{array}{llll}\text { Rotation Sums of Squared } \\
\text { Loadings }\end{array}$} \\
\hline & Total & $\begin{array}{l}\% \text { of } \\
\text { Variance }\end{array}$ & $\begin{array}{l}\text { Cumulative } \\
\%\end{array}$ & Total & $\begin{array}{l}\% \text { of } \\
\text { Variance }\end{array}$ & $\begin{array}{l}\text { Cumulative } \\
\%\end{array}$ & Total & $\begin{array}{l}\% \text { of } \\
\text { Variance }\end{array}$ & $\begin{array}{l}\text { Cumulative } \\
\%\end{array}$ \\
\hline 1 & 6.267 & 41.781 & 41.781 & 6.267 & 41.781 & 41.781 & 4.919 & 32.796 & 32.796 \\
\hline 2 & 5.058 & 33.718 & 75.499 & 5.058 & 33.718 & 75.499 & 4.668 & 31.122 & 63.918 \\
\hline 3 & 1.249 & 8.324 & 83.823 & 1.249 & 8.324 & 83.823 & 2.986 & 19.905 & 83.823 \\
\hline 4 & .863 & 5.751 & 89.574 & & & & & & \\
\hline 5 & .689 & 4.592 & 94.166 & & & & & & \\
\hline 6 & .429 & 2.863 & 97.028 & & & & & & \\
\hline 7 & .156 & 1.042 & 98.070 & & & & & & \\
\hline 8 & .113 & .752 & 98.823 & & & & & & \\
\hline 9 & .078 & .523 & 99.346 & & & & & & \\
\hline 10 & .041 & .276 & 99.622 & & & & & & \\
\hline 11 & .020 & .134 & 99.756 & & & & & & \\
\hline 12 & .019 & .127 & 99.883 & & & & & & \\
\hline 13 & .009 & .060 & 99.943 & & & & & & \\
\hline
\end{tabular}

Extraction Method: Principal Component Analysis.

Factor 1: $\mathrm{Mo}, \mathrm{Cu}, \mathrm{Pb}, \mathrm{Zn}, \mathrm{As}, \mathrm{Sr}$ and $\mathrm{Cd}$

Factor 1 which explains $32.796 \%$ of the system variance (Table 8), has a high positive factor loading on $\mathrm{Mo}, \mathrm{Cu}$, $\mathrm{Pb}, \mathrm{Zn}$, and $\mathrm{Cd}$ (Table 7), and a moderate positive factor loading on As and Sr. Elemental association in Factor 1 is influenced mainly by Felsic mineral-rich lithology, anthropogenic influences and geochemical behaviour. According to Goldschmidt $\mathrm{Cu}, \mathrm{Pb} \mathrm{Zn}$ As and $\mathrm{Cd}$ are all chalcophilic, while Mo can behave both as chalcophile and lithophile in the earth's surface.

\section{Factor 2: $\mathrm{Ni}, \mathrm{Co}, \mathrm{Mn}, \mathrm{Sc}, \mathrm{Sr}, \mathrm{V}$ and $\mathrm{Cr}$}

Factor 2 which explain $31.122 \%$ of the total system variance (Table 8), has a high positive factor loading on $\mathrm{Ni}, \mathrm{Co}, \mathrm{Mn}$ and $\mathrm{Sr}$ and a moderate positive factor loading on Sc, $\mathrm{V}$ and $\mathrm{Cr}$ (Table 7). The elemental association in Factor 2 is controlled mainly by geochemical affinity and mafic mineral-rich lithologies. All the metals in this group are siderophilic.

\section{Factor 3: Sc and V}

Factor 3 which accounts for $19.905 \%$ of the total system variance (Table 8), has a moderate positive factor loading on $\mathrm{Sr}$ and a high positive factor loading on $\mathrm{Sc}$ (Table 7). The association of elements in this factor is influenced by both mafic mineral-rich lithology, and geochemical affinity.

\subsection{CONTAMINATION INDICES}

3.5. Geoaccumulation Index ( $\left.I_{\text {geo }}\right)$

Geoaccumulation indices were calculated using value from a controlled sample from Olapiti village (Table 8) as background for each metal. This area is remote, and lack any modern producing company. Industrial influence in this area is therefore minimal.

Table 8: Result of sample from Olapiti village close to Oyo Town

\begin{tabular}{|l|l|l|l|l|l|l|l|l|l|l|l|l|l|}
\hline & $\begin{array}{l}\text { Mo } \\
\text { Ppm }\end{array}$ & $\begin{array}{l}\text { Cu } \\
\text { ppm }\end{array}$ & $\begin{array}{l}\mathrm{Pb} \\
\text { ppm }\end{array}$ & $\begin{array}{l}\text { Zn } \\
\text { ppm }\end{array}$ & $\begin{array}{l}\text { Ni } \\
\text { ppm }\end{array}$ & $\begin{array}{l}\text { Co } \\
\text { ppm }\end{array}$ & $\begin{array}{l}\text { Mn } \\
\text { ppm }\end{array}$ & $\begin{array}{l}\text { Sc } \\
\text { ppm }\end{array}$ & $\begin{array}{l}\text { As } \\
\text { ppm }\end{array}$ & $\begin{array}{l}\text { Sr } \\
\text { ppm }\end{array}$ & $\begin{array}{l}\text { Cd } \\
\text { ppm }\end{array}$ & $\begin{array}{l}\text { V } \\
\text { ppm }\end{array}$ & $\begin{array}{l}\text { Cr } \\
\text { ppm }\end{array}$ \\
\hline L1 & 0.9 & 20.3 & 20.9 & 22 & 13.6 & 23.1 & 1054 & 4.8 & 0.4 & 12 & 0.09 & 89 & 85 \\
\hline L2 & 0.5 & 24.9 & 24.2 & 28 & 11.8 & 16.7 & 1286 & 2.4 & 0.4 & 82 & 0.1 & 38 & 29 \\
\hline L3 & 0.8 & 21.5 & 21.5 & 24 & 14.4 & 23.6 & 1068 & 5.0 & 0.6 & 11 & 0.1 & 95 & 91 \\
\hline L4 & 0.7 & 14.2 & 24.9 & 297 & 7.2 & 8.4 & 690 & 2.4 & 0.4 & 15 & 0.1 & 40 & 31 \\
\hline L5 & 0.5 & 8.8 & 33.3 & 145 & 5.5 & 6.5 & 504 & 1.7 & 0.4 & 21 & 0.09 & 28 & 23 \\
\hline L6 & 0.8 & 10.3 & 25.1 & 176 & 8.2 & 8.1 & 501 & 2.2 & 0.5 & 9 & 0.09 & 39 & 30 \\
\hline L7 & 0.6 & 12.0 & 16.1 & 83 & 5.7 & 7.7 & 404 & 1.4 & 0.4 & 10 & 0.09 & 31 & 28 \\
\hline L8 & 0.6 & 11.8 & 17.7 & 36 & 10.5 & 14.8 & 676 & 2.5 & 0.4 & 14 & 0.09 & 40 & 27 \\
\hline L9 & 0.5 & 22.3 & 14.3 & 50 & 7.8 & 12.1 & 578 & 1.3 & 0.4 & 27 & 0.09 & 24 & 17 \\
\hline L10 & 2.5 & 19.2 & 35.7 & 25 & 8.8 & 9.5 & 484 & 4.7 & 2.2 & 7 & 0.09 & 110 & 127 \\
\hline Mean & $\mathbf{0 . 8}$ & $\mathbf{1 6 . 5}$ & $\mathbf{2 3 . 4}$ & $\mathbf{8 9}$ & $\mathbf{9 . 4}$ & $\mathbf{1 3 . 1}$ & $\mathbf{7 2 5}$ & $\mathbf{2 . 8}$ & $\mathbf{0 . 6}$ & $\mathbf{2 1}$ & $\mathbf{0 . 0 9}$ & $\mathbf{5 3}$ & $\mathbf{4 9}$ \\
\hline
\end{tabular}


The range of Geoaccumulation indices for the soils of the study area is presented in Table 9.

Table 9: Range of Geoaccumulation indices for soils of Oluyole Industrial Estate

\begin{tabular}{|l|l|l|}
\hline Metals & Minimum & Maximum \\
\hline $\mathrm{Mo}$ & -1.0 & 1.1 \\
\hline $\mathrm{Cu}$ & -0.6 & 1.6 \\
\hline $\mathrm{Pb}$ & -1.6 & 2.9 \\
\hline $\mathrm{Zn}$ & -3.0 & 1.0 \\
\hline $\mathrm{Ni}$ & -0.2 & 2.7 \\
\hline $\mathrm{Co}$ & -1.2 & 1.6 \\
\hline $\mathrm{Mn}$ & -2.0 & 0.0 \\
\hline $\mathrm{Sc}$ & -1.6 & 0.8 \\
\hline $\mathrm{As}$ & -0.6 & 1.9 \\
\hline $\mathrm{Sr}$ & -1.0 & 2.0 \\
\hline $\mathrm{Cd}$ & -0.7 & 1.4 \\
\hline $\mathrm{V}$ & -1.0 & 1.0 \\
\hline $\mathrm{Cr}$ & -1.0 & 1.0 \\
\hline
\end{tabular}

Mo ranged from -1.0 to 1.1 indicating asoil that is practically uncontaminated to moderately contaminated in Mo (Table 9).Cu ranged from -0.6 to 1.6 which showed that the soils were practically uncontaminated to moderately contaminated in $\mathrm{Cu}$ (Table 9).Pb ranged from -1.6 to 2.9 indicating a soil that is practically uncontaminated to moderately to heavily contaminated by $\mathrm{Pb}$ (Table 9). The high value of $\mathrm{Pb}$ in the area could be linked to automobile emissions, and wear and tear of tyres. $\mathrm{Zn}$ ranged from -3.0 to 1.0 which showed that the soil is practically uncontaminated to moderately contaminated by $\mathrm{Zn}$ (Table 9). Ni ranged from -0.2 to 2.7 which showed that the soilsare practically uncontaminated to heavily contaminated by $\mathrm{Ni}$ (Table 9). The highest concentration of $\mathrm{Ni}(2.7)$ in the soils is attributed to the contributions of mechanic workshop in that area. Co ranged from -1.2 to 1.6 showing that the soils are practically uncontaminated to moderately contaminated by Co (Table 9). The concentration of Co could be linked to Lithium cobalt oxide $\left(\mathrm{LiCoO}_{2}\right)$ which is widely used in lithium ion battery as cathode. Mn ranged from -2.0 to 0.3 which showed that the soils are practically uncontaminated to moderately contaminated by $\mathrm{Mn}$ (Table 9). Cd ranged from -0.7 to 0.0 indicating that the soils are practically uncontaminated by $\mathrm{Cd}$ (Table 9 ). Cr ranged from -1.0 to 1 which showed that the soils are practically uncontaminated to moderately contaminated by $\mathrm{Cr}$ (Table 9). Sr ranged from -1.0 to 2.0 showing that the soils are practically uncontaminated to moderately to heavily contaminated by $\mathrm{Sr}$ (Table 9). V ranged from 1.0 to 1.0 which showed that the soils are practically uncontaminated to moderately by $\mathrm{V}$ (Table 10).Sc ranged from -1.6 to 0.8 , which showed that they are practically uncontaminated to moderately contaminated by Sc (Table 9).As ranged from -0.6 to 1.9 which showed that the soils are practically uncontaminated to moderately contaminated by As.

The percentage of metal in each class of geoaccumulation index and the percentage of metal contamination in the study area is as shown in Table 10 and Figure 4 respectively, while the range of geoaccumulation indices for each metal is shown in Figure 5. 
Table 10: Percentage of Metals in each class of Geoaccumulation Index for soils of the study area

\begin{tabular}{|c|c|c|c|c|c|c|c|c|c|c|c|c|c|c|c|}
\hline Class & $\begin{array}{l}\text { Igeo } \\
\text { Value }\end{array}$ & Soil Quality & $\begin{array}{l}\% \\
\text { Mo }\end{array}$ & $\begin{array}{l}\% \\
\mathrm{Cu}\end{array}$ & $\begin{array}{l}\% \\
\mathrm{~Pb}\end{array}$ & $\begin{array}{l}\% \\
\mathrm{Zn}\end{array}$ & $\begin{array}{l}\% \\
\mathrm{Ni}\end{array}$ & $\begin{array}{l}\% \\
\text { Co }\end{array}$ & $\begin{array}{l}\% \\
\text { Mn }\end{array}$ & $\begin{array}{l}\% \\
\text { Sc }\end{array}$ & $\begin{array}{l}\% \\
\text { As }\end{array}$ & $\begin{array}{l}\% \\
\mathrm{Sr}\end{array}$ & $\begin{array}{l}\% \\
\text { Cd }\end{array}$ & $\begin{array}{l}\% \\
\mathrm{~V}\end{array}$ & $\begin{array}{l}\% \\
\mathrm{Cr}\end{array}$ \\
\hline 0 & $\begin{array}{l}\lg e 0 \leq \\
0\end{array}$ & $\begin{array}{l}\text { Practically } \\
\text { Uncontaminated }\end{array}$ & 62 & 10 & 48 & 57 & 10 & 29 & 57 & 81 & 10 & 53 & 62 & 29 & 5 \\
\hline 1 & $\begin{array}{l}0< \\
\operatorname{lgeo} \leq \\
1\end{array}$ & $\begin{array}{l}\text { Uncontaminated } \\
\text { to Moderately } \\
\text { Contaminated }\end{array}$ & 33 & 76 & 33 & 43 & 48 & 57 & 43 & 19 & 76 & 23 & 24 & 61 & 95 \\
\hline 2 & $\begin{array}{l}1 \\
\operatorname{lgeo} \leq \\
2\end{array}$ & $\begin{array}{l}\text { Moderately } \\
\text { Contaminated }\end{array}$ & 5 & 14 & 14 & nil & 23 & 14 & nil & nil & 14 & 19 & 14 & 10 & nil \\
\hline 3 & $\begin{array}{l}2< \\
\operatorname{lgeo} \leq \\
3\end{array}$ & $\begin{array}{l}\text { Moderate to } \\
\text { Heavily } \\
\text { Contaminated }\end{array}$ & nil & nil & nil & nil & 19 & nil & nil & nil & nil & 5 & nil & nil & nil \\
\hline 4 & $\begin{array}{l}3< \\
\text { lgeo } \leq \\
4\end{array}$ & $\begin{array}{l}\text { Heavily } \\
\text { Contaminated }\end{array}$ & nil & nil & nil & nil & nil & nil & nil & nil & nil & nil & nil & nil & nil \\
\hline 5 & $\begin{array}{l}4 \\
\operatorname{lgeo} \leq \\
5\end{array}$ & $\begin{array}{l}\text { Heavily to } \\
\text { Extremely } \\
\text { Contaminated }\end{array}$ & nil & nil & nil & nil & nil & nil & Nil & nil & nil & nil & nil & nil & nil \\
\hline 6 & $\begin{array}{l}\operatorname{lgeo}> \\
5\end{array}$ & $\begin{array}{l}\text { Extremely } \\
\text { Contaminated }\end{array}$ & nil & nil & nil & nil & nil & nil & Nil & nil & nil & nil & nil & nil & nil \\
\hline
\end{tabular}

\section{Percentage metal contamination of the study area}

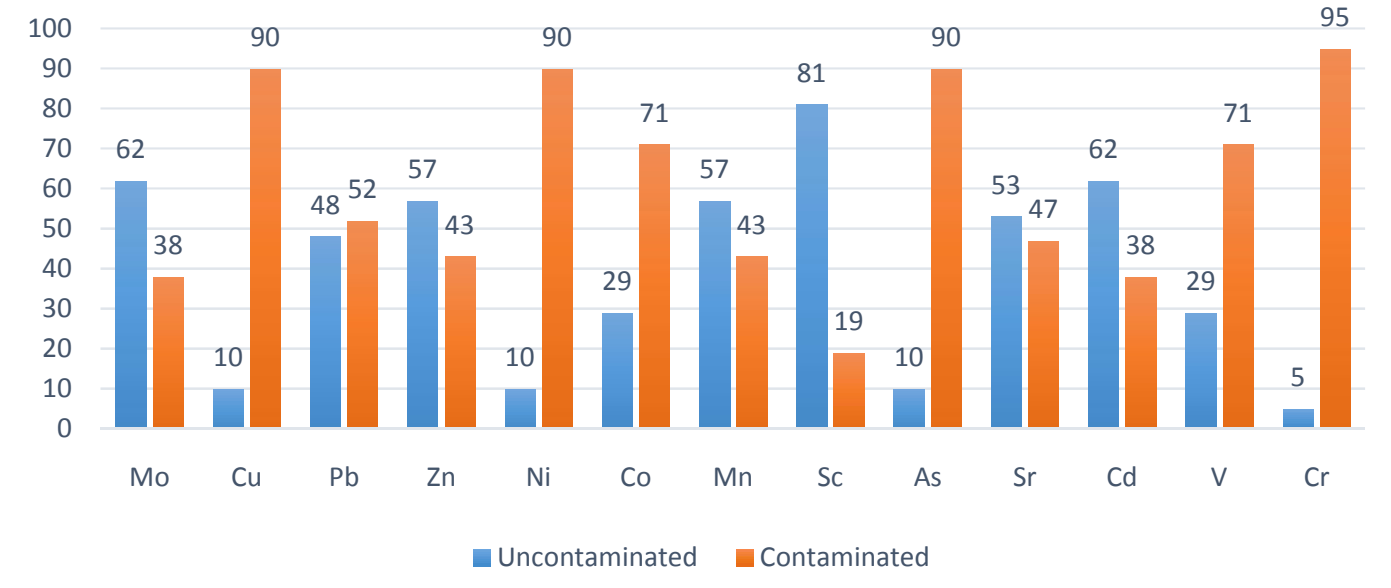

Figure 4: Percentage Metal contamination 


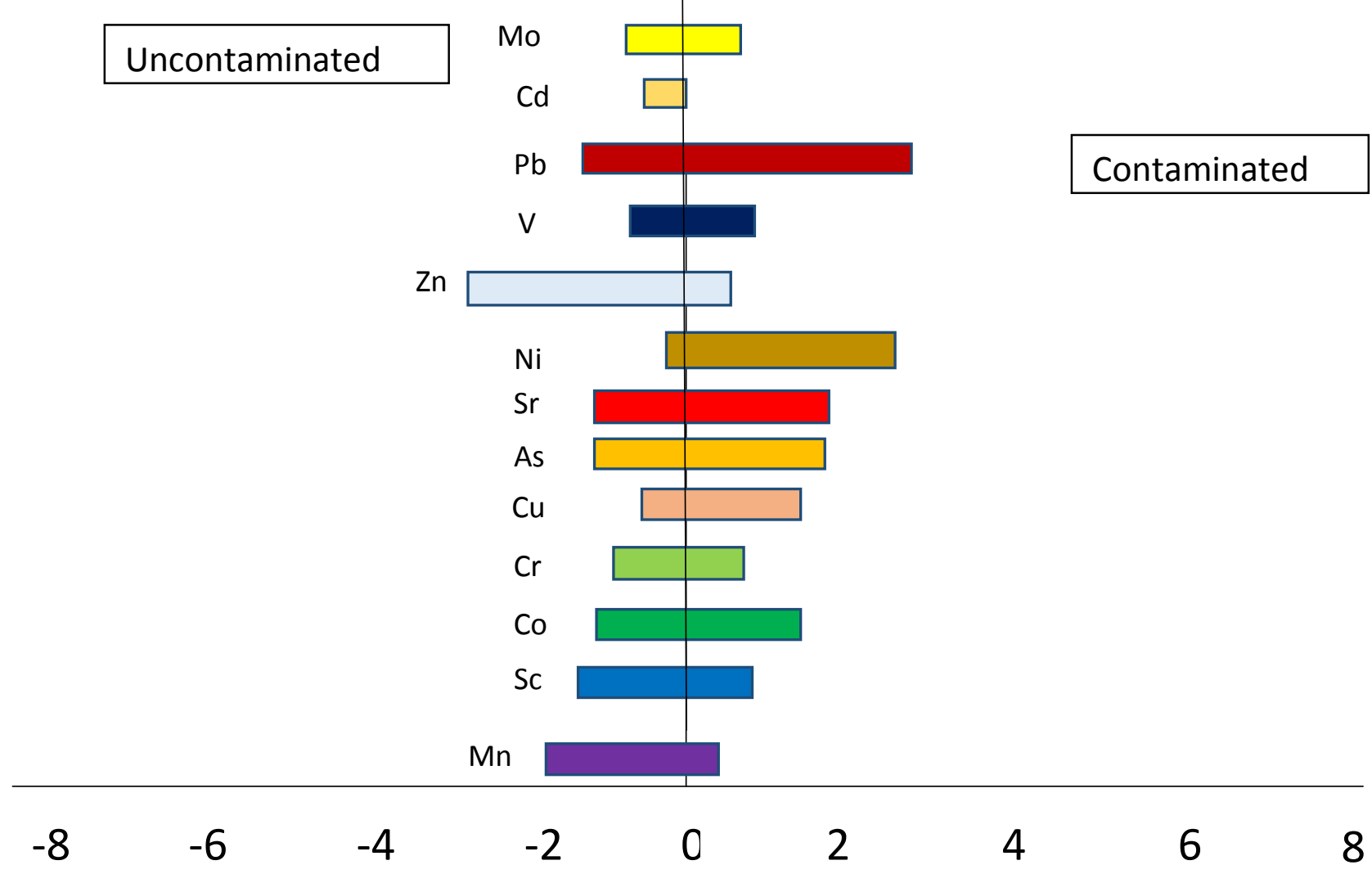

Figure 5: Geoaccumulation Index (Igeo) for metal of the study area

3.6. Contamination Factor and Degree of Contamination

The level of contamination in the soils of the study area as shown by the categories of contamination factor is presented in Table 11 and Figure 6.

Table 11: Contamination Factors for the Soils of the study area

\begin{tabular}{|c|c|c|c|c|c|c|c|c|c|c|c|c|c|c|}
\hline Categories & & Mo & $\mathrm{Cu}$ & $\mathrm{Pb}$ & $\mathrm{Zn}$ & $\mathrm{Ni}$ & Co & Mn & Sc & As & $\mathrm{Sr}$ & Cd & V & $\mathrm{Cr}$ \\
\hline$C_{f}^{\prime}<1$ & $\begin{array}{l}\text { Low Contamination } \\
\text { factor }\end{array}$ & & & & & & & & & & & & & \\
\hline $1 \leq \mathrm{C}_{\mathrm{f}}^{\prime}<3$ & $\begin{array}{l}\text { Moderate Contaminatior } \\
\text { Factor }\end{array}$ & 1.40 & 2.10 & 2.00 & 1.00 & & 2.00 & 1.03 & 1.40 & 2.00 & 2.00 & 2.00 & 1.00 & 1.80 \\
\hline $3 \leq C_{f}^{i}<6$ & $\begin{array}{l}\text { Considerable } \\
\text { Contamination } \\
\text { factor }\end{array}$ & & & & & 4.00 & & & & & & & & \\
\hline$C_{f}^{i} \geq 6$ & $\begin{array}{l}\text { Very High Contaminatio } \\
\text { Factor }\end{array}$ & & & & & & & & & & & & & \\
\hline
\end{tabular}




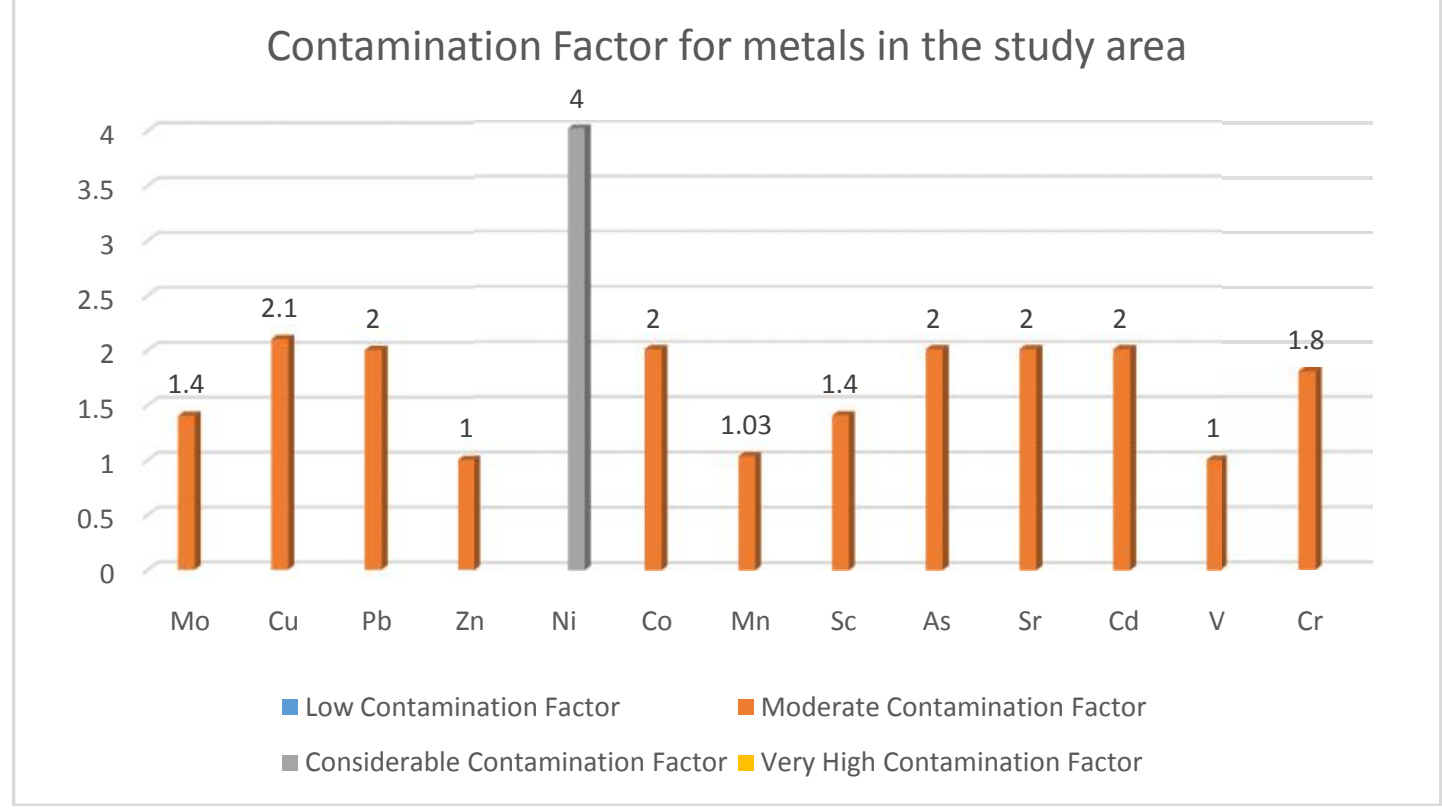

Fig 6: Contamination factor for metals in the soils of the study area

The soils of Oluyole Industrial estate showed a Moderate Contamination Factor for all the metals studied excepting only $\mathrm{Ni}$. The Contamination Factor values are as follows: $\mathrm{Mn}$ (1.03), Mo (1.40), Cu (2.10), Zn (1.00), Co (2.00), Sc (1.40), As (2.00), Sr (2.00), V (1.00), Cr (1.80), Pb (2.00), Cd (2.00) andNi (4.00), which showed a considerable factor of contamination.
The degree of contamination which gives an assessment of the overall contamination of the soils of the study area is presented in Table 12. The quantification of the overall Degree of Contamination (28.23) of the soils of Oluyole industrial estate indicated a Considerable Degree of metal contamination (Table 13).

Table 12: Hakanson's Categories of Contamination degree

\begin{tabular}{|c|c|c|}
\hline \multicolumn{2}{|c|}{$\begin{array}{l}\text { Class of Contamination Soil Category } \\
\text { degree }\end{array}$} & $\begin{array}{l}\text { Degree of contamination } \\
\text { for the studied soils }\end{array}$ \\
\hline $\begin{array}{l}\mathrm{C}_{\text {deg }}<8 \\
8 \leq \mathrm{C}_{\text {deg }} 16 \\
16 \leq \mathrm{C}_{\text {deg }} 32 \\
32 \leq \mathrm{C}_{\text {deg }}\end{array}$ & $\begin{array}{l}\text { Low degree of contamination } \\
\text { Moderate degree of contamination } \\
\text { Considerable degree of contamination } \\
\text { Very high degree of contamination }\end{array}$ & 28.23 \\
\hline
\end{tabular}

\section{CONCLUSIONS}

The mean concentration of the metals in the soils around Oluyole industrial estate area of lbadan as shown by this study was in the order $\mathrm{Mn}>\mathrm{Cr}>\mathrm{Zn}>\mathrm{Pb}>\mathrm{Cu}>\mathrm{Ni}>\mathrm{Sr}>\mathrm{Co}>\mathrm{Sc}>\mathrm{As}>\mathrm{Mo}>\mathrm{Cd}$. Factor analysis yielded three factor groupings; Factor 1: Mo, $\mathrm{Cu}, \mathrm{Pb}, \mathrm{Zn}, \mathrm{As}, \mathrm{Sr}$ and $\mathrm{Cd}$ were mainly sourced from felsic mineral-rich lithologies and anthropogenic activities. Factor 2: $\mathrm{Ni}, \mathrm{Co}, \mathrm{Mn}, \mathrm{Sc}, \mathrm{Sr}, \mathrm{V}$ and $\mathrm{Cr}$ were sourced mainly from mafic mineral-rich lithologies and influence by geochemical affinity. Factor 3 : Sc and V were sourced mainly from mafic mineral-rich lithologies and further influenced by geochemical affinity. Generally, the elemental association in the soils was influenced by lithology, geochemical affinity and anthropogenic activities. Results of Geoaccumulation Index showed that the soils were Practically uncontaminated to Uncontaminated/Moderately contaminated by $\mathrm{Zn}, \mathrm{Mn}$, Sc and $\mathrm{Cr}$, moderately contaminated by $\mathrm{Mo}, \mathrm{Cu}, \mathrm{Pb}, \mathrm{Ni}, \mathrm{Co}, \mathrm{As}, \mathrm{Cd}$, moderate to heavily contaminated by $\mathrm{Ni}$ and $\mathrm{Sr}$. Moreover, the soil showed Moderate Contamination Factor for all the studied metals excepting Ni which showed Considerable Contamination factor. Overall the soils have considerable degree of contamination value of 28.23. Generally, the considerable degree of contamination for the study area by the studied metals and the considerable factor of contamination for $\mathrm{Ni}$ indicated an area with possible health danger to plant, animal and man.Most of the metal contamination of soils in this area derives from industrial activities in the area. 
Consequently, it is recommended that these industries improve on their waste disposal techniques in order to reduce the risk posed to the environment through the current practice of indiscriminate disposal of their waste products.

\section{REFERENCES}

Dada, S. S., 2006. Proterozoic Evolution of Nigeria. In Oshin. O, ed. The Basement Complex of Nigeria and its Mineral Resources (A Tribute to Prof. M. A. O. Rahaman). Akin Jinad and Co Ibadan, 29 $-44$.

Filani, M. O and Akintola, F. O., 1982. Ibadan Region, University of Ibadan, Ibadan.

Grant, N. K., 1970. Geochronology of Precambrian Basement rocks from Ibadan. Earth Sci Newslett 10: 29-38

Hakanson, L., 1980. An ecological risk index for aquatic pollution control: a sedimentological approach. Water Res., 14:975-1001.

Jones, H. A and Hockey, R. D., 1964. The Geology of part of southwestern Nigeria. Geological Survey of Nigeria Bull, (31): 87.

Loska, K., Wiechula, D and Korus, I., 2004. Metal contamination of Farming soils affected by industry. Environ. International, 30: 159-165.

Muller, G.,1969. Index of geoaccumulation in sediments of the Rhine River. Geo. J., 2, (3): 108-118. (11 pages).

Mtunzi, F. M., Dikko, E. D and Moja, S. J., 2015. Evaluation of heavy metal pollution on soil in
Varderbijl Park, South Africa. International Journal of Environmental Monitoring and Analysis, 3(2): 44-49

Obaje, N. G., 2009. Geology and Mineral Resources of Nigeria. Lecture Notes in Earth Scinces 120.Springers-Verlag Berlin Heidelberg.p.219.

Olayinka, A. I., 1992. Geophysical siting of boreholes in crystalline basement areas of Africa. Journal of African Earth Sciences, 14, 197-207.

Olukanmi, D. O and Adeoye, D. O., 2012. Heavy metal concentrations in road side Soils from selected locations in Lagos Metropolis, Nigeria. International Journal of Engineering and Technology. 2, (10): $1743-1752$.

Popoola, O. E., Bamgbose, O., Okonkwo, O. J., Arowolo, T. A., Odukoya, O and Popoola, A. O., 2012. Heavy metal content in Playground topsoil of some public primary schools in metropolitan Lagos, Nigeria. Research Journal of Environmental and Earth Sciences. 4, (4): 434 439.

Rahaman, M. A., 1976. Review of the basement geology of south-western Nigeria. In: Geology of Nigeria, Kogbe, C.A. (ed.), Elizabethan Press: Lagos. 41-58.

Rahaman, M. A., 1988. Recent Advances in the study of the Basement Complex of Nigeria in: Precambrian Geology of Nigeria, edited by P.O. Oluyole. A publication of the Geological survey of Nigeria., 11-44. 
APPENDIX

Statistical summary of elemental concentrations in the soils of Oluyole industrial estate

\begin{tabular}{|l|l|l|l|l|l|l|}
\hline & N & Minimum & Maximum & Sum & Mean & $\begin{array}{l}\text { Std. } \\
\text { Deviation }\end{array}$ \\
\hline $\mathrm{Mo}$ & 21 & .60 & 2.50 & 24.70 & 1.18 & .52 \\
$\mathrm{Cu}$ & 21 & 16.20 & 76.00 & 736.30 & 35.06 & 14.83 \\
$\mathrm{~Pb}$ & 21 & 11.40 & 270.80 & 1089.7 & 51.89 & 56.66 \\
$\mathrm{Zn}$ & 21 & 19.00 & 243.00 & 1918.00 & 91.33 & 56.80 \\
$\mathrm{Ni}$ & 21 & 12.60 & 94.30 & 726.20 & 34.58 & 22.32 \\
$\mathrm{Co}$ & 21 & 8.40 & 60.30 & 543.20 & 25.87 & 12.24 \\
$\mathrm{Mn}$ & 21 & 266.00 & 1397.00 & 15694.00 & 747.33 & 287.64 \\
$\mathrm{Sc}$ & 21 & 1.40 & 7.50 & 71.50 & 3.40 & 1.74 \\
$\mathrm{As}$ & 21 & .60 & 3.40 & 28.30 & 1.35 & 0.59 \\
$\mathrm{Sr}$ & 21 & 13.00 & 90.00 & 682.00 & 32.48 & 19.21 \\
$\mathrm{Cd}$ & 21 & .09 & .40 & 3.22 & .15 & .09 \\
$\mathrm{~V}$ & 21 & 30.00 & 127.00 & 1530.00 & 72.86 & 23.85 \\
$\mathrm{Cr}$ & 21 & 45.00 & 145.00 & 1927.00 & 91.76 & 28.55 \\
$\mathrm{~V}$ & & & & & \\
(listwise) & 21 & & & & & \\
\hline
\end{tabular}

